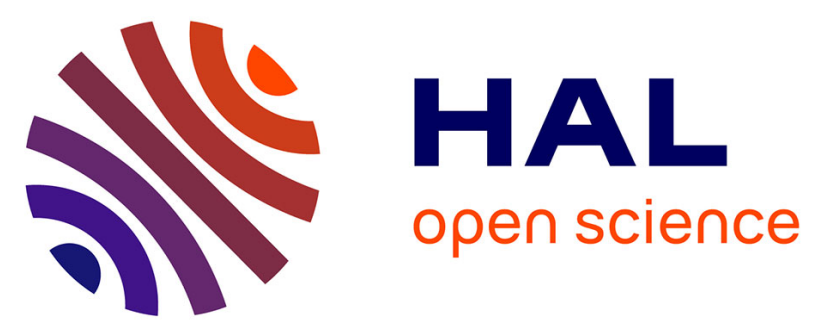

\title{
Epsilonproteobacteria as gill epibionts of the hydrothermal vent gastropod Cyathermia 1 naticoides (North East-Pacific Rise)
}

Magali Zbinden, Lise Marqué, Sylvie Marylène Gaudron, Juliette Ravaux, Nelly Léger, Sébastien Duperron

\section{To cite this version:}

Magali Zbinden, Lise Marqué, Sylvie Marylène Gaudron, Juliette Ravaux, Nelly Léger, et al.. Epsilonproteobacteria as gill epibionts of the hydrothermal vent gastropod Cyathermia 1 naticoides (North East-Pacific Rise). Marine Biology, 2014, 162 (2), pp.435-448. 10.1007/s00227-014-2591-7 . hal01117192

\section{HAL Id: hal-01117192 \\ https://hal.sorbonne-universite.fr/hal-01117192}

Submitted on 16 Feb 2015

HAL is a multi-disciplinary open access archive for the deposit and dissemination of scientific research documents, whether they are published or not. The documents may come from teaching and research institutions in France or abroad, or from public or private research centers.
L'archive ouverte pluridisciplinaire HAL, est destinée au dépôt et à la diffusion de documents scientifiques de niveau recherche, publiés ou non, émanant des établissements d'enseignement et de recherche français ou étrangers, des laboratoires publics ou privés. 
Epsilonproteobacteria as gill epibionts of the hydrothermal vent gastropod Cyathermia naticoides (North East-Pacific Rise)

Magali Zbinden ${ }^{1}$, Lise Marqué ${ }^{1}$, Sylvie Marylène Gaudron ${ }^{1,2}$, Juliette Ravaux ${ }^{1}$, Nelly Léger ${ }^{1}$, Sébastien Duperron ${ }^{1}$

${ }^{1}$ Sorbonne Universités, Université Pierre et Marie Curie Paris 06, UMR7208 MNHN CNRS UPMC IRD Biologie des Organismes Aquatiques et Ecosystèmes, Equipe Adaptation aux Milieux Extrêmes, 7 quai St Bernard, 75252 Paris Cedex 05, France

${ }^{2}$ Present address: UMR8187 Laboratoire d'Océanologie et de Géosciences (UL1 CNRS ULCO), Station marine de Wimereux, 28 avenue Foch, 62930 Wimereux, France

Corresponding author : M. Zbinden, email: magali.zbinden@upmc.fr, phone : 003314427 37 93, fax : 0033144275801

\section{$\underline{\text { Abstract }}$}

Molluscs, and particularly gastropods, are one of the major taxonomic groups at vents. In these ecosystems, devoid of light, chemoautotrophic bacteria are at the base of the food web, and symbiotic association between metazoa and these bacteria are numerous. Nevertheless, apart few "large size" well known species, the "small size" gastropods (shell < 5mm), although very abundant, remain poorly studied regarding symbioses. We investigated here Cyathermia naticoides (Warén and Bouchet 1989), a small coiled gastropod found in abundance on the East Pacific Rise among Riftia pachyptila tubes and usually inferred to graze on tubeworms bacterial cover, and/or filter feeding. Among molluscs, symbioses are well known in large species and almost exclusively rely on sulfide or methane-oxidizing Proteobacterial endosymbionts, occurring within the host tissues in gill epithelial bacteriocytes. Combining several approaches (molecular biology, microscopy, stable isotopes analyses), we described here an unusual symbiosis, where autotrophic filamentous Epsilonproteobacteria are located extracellularly, at the base of hosts gill filaments. Numerous endocytotic lysosome-like structures were observed in the gill epithelium of the animal suggesting bacteria may contribute to its nutrition through intracellular digestion by gill cells. Additional food source by non-symbiotic Proteobacteria grazed on $R$. pachyptila tubes could complete the diet. The possible role of temperature in the selection of Epsilon vs Gamma proteobacterial partners is discussed. 


\section{Introduction}

To date, about 600 metazoan species have been reported at hydrothermal vents, belonging to 12 phyla. Among those, 150 species of Mollusca and more than 100 species of Gastropoda have been described (Desbruyères et al. 2006), making them one of the major taxonomic groups at vents. Gastropod feeding habits are extremely diverse, although most species make use of a radula in some aspect of their feeding behavior (see review in Kohn 1983). Grazers can be herbivorous, rasping either micro- or macroalgae, or predators, rasping on encrusting invertebrates such as hydroids, sponges, cnidarians or ascidians. Herbivorous may also swallow sand containing algae. And carnivores may also hunt their prey and use their radula to drill mollusc shells or calcareous echinoids test, or perforate prey soft tissues (polychaetes, fishes,...). Some predators have lost the radula and engulf animal prey whole. Various feeding modes, using no radula, are also encountered in gastropods. In filter feeders, hypertrophy of the ctenidium as a ciliray-mucous food collecting device is used as a trap to capture and sort particles suspended in seawater. Other feeding strategies include parasitic species, devoid of radula, that feed on body fluids thank to a sucker, and establishment of nutritional symbioses. Some herbivorous species can suck algal cell content and establish symbioses with chloroplastes (family Elysiidae) or zooxanthellae (family Aeolidae). Chemoautotrophic symbioses also occur in a wide range of habitats, including cold seeps, whale and wood falls, shallow-water coastal sediments and continental margins (Dubilier et al. 2008).

In the hydrothermal vent environment, chemosynthetic production by bacteria is the main food source of primary consumers (Felbeck and Somero 1982). The majority of hydrothermal gastropods are thus grazers or filter feeders that appear to feed on free-living bacteria (Bates 2007a). Another widespread strategy at vents is symbiotic association with chemoautotrophic bacteria. Up to now, such symbioses have been demonstrated in at least 7 different phyla (Dubilier et al. 2008), including molluscs, the most famous examples being described in gills of bivalves (Bathymodiolinae and Vesicomyidae) and involve sulfur-oxidizing Gammaproteobacteria endosymbionts. But it also exists among gastropods. The best known examples are Alviniconcha hessleri and Ifremeria nautilei, found in the western Pacific (Windoffer and Giere 1997; Borowski et al. 2002; Suzuki et al. 2005a, 2005b, 2006; Urakawa et al. 2005; Saito and Hashimoto 2010). Most of the examples described for these two species also rely on sulfur-oxidizing Gammaproteobacteria gill endosymbionts. But recently, Epsilonproteobacteria were described as gill endosymbionts in some species of Provannidae (Urakawa et al. 2005; Suzuki et al. 2006, Beinart et al. 2013). Symbioses in smaller gastropod species remain poorly studied and the presence of bacteria as symbionts has only been 
documented in Lepetodrilus fucensis from the Juan de Fuca Ridge (Bates 2007a ), in which a nutritional role has been suggested.

In this study, we investigate a coiled gastropod, the Neomphalina Cyathermia naticoides (Warén and Bouchet 1989). Not much is known about it, despite it is a common species, found in abundance among Riftia pachyptila clumps (Mills et al. 2007), and in lower abundances among Alvinella pompejana and Bathymodiolus thermophilus (Warén et al. 2006). Up to now, $C$. naticoides was inferred to graze on tubeworms bacterial cover, but also to use filter feeding, based on its very large bipectinate gill (Warén and Bouchet 1989). A distinct labial notch described by Warén and Bouchet (1989) in the shell morphology is interpreted as an adaptation to allow the gill to be extended outside the shell even when the snail is resting on the substrate, partially retracted into the shell (Warén and Bouchet 1989; Sasaki et al. 2010). Here we investigate an additional hypothesis as feeding strategy in $C$. naticoides. Our study describes a unusual symbiosis, where epibiotic autotrophic Epsilonproteobacteria are endocytosed within the gill filaments of the animal. The large size of the gill, the recurrent observation of endocytosis and lysis of bacteria, and the stable isotopes results advocate for a nutritional symbiosis.

\section{Material and methods}

Animal collection and conditioning. Cyathermia naticoides specimens were collected, among Riftia pachyptila tubes, using the DSV Nautile during the Mescal 2010 cruise (East Pacific Rise, 2,500 m depth), on two different sites : 950'N (Bio9 site) and 1250'N (Genesis site). Once on board, the entire specimens were fixed (operculum removed) in: 1) $2.5 \%$ glutaraldehyde (for light and electron microscopies), 2) ethanol (for DNA extraction), 3) 24\% formaldehyde (for Fluorescent In Situ Hybridization, FISH) and 4) liquid nitrogen (for stable isotope analyses and chitinase activity assays).

Light and Electron Microscopies. Gut and gill tissues of 3 specimens of $C$. naticoides from $9^{\circ} 50^{\prime} \mathrm{N}$ were dissected. Two other specimens were embedded whole. Samples were post-fixed in osmium tetroxide 1\%, dehydrated in increasing ethanol series (50, 70, 95 and 100\%) and embedded in Epon resin $\left(48 \mathrm{~h}, 60^{\circ} \mathrm{C}\right)$. Sections were cut using a Reichert-Jung ultramicrotome. Semi-thin $(600 \mathrm{~nm})$ sections were stained with toluidine blue and observed with an Olympus BX 61. Thin $(60 \mathrm{~nm})$ sections were mounted on copper grids, contrasted using uranyl acetate and observed using a HITACHI H-7100 transmission electron 
microscope, operated at $80 \mathrm{kV}$.

\section{Fluorescence In situ hybridization (FISH)}

109 Four specimens from $9^{\circ} 50^{\prime} \mathrm{N}$ and 2 from $12^{\circ} 50^{\prime} \mathrm{N}$ were used. Specimens were pulled out their shells, and after 2-4 hours in 4\% formaldehyde, were rinsed and dehydrated in 50, 70 and $96 \%$ ethanol. They were then embedded whole in polyethylene glycol (PEG) distearate: 1hexadecanol (9:1). Sections of 7-10 $\mu \mathrm{m}$ were cut using a Jung microtome and deposited on Superfrost Plus slides. Wax was removed and tissue rehydrated in decreasing ethanol series. Sections were hybridized as described in Zbinden et al. (2010), using 30\% formamide for 3 hours at $46^{\circ} \mathrm{C}$, rinsed $\left(15 \mathrm{~min}, 48^{\circ} \mathrm{C}\right)$, covered with SlowFade containing DAPI, and examined under an Olympus BX-61 epifluorescence microscope (Olympus, Japan). Following probes, labeled with Cy-3 and Cy-5, were used: Eub-338 (5'GCTGCCTCCCGTAGGAGT-3', Amann et al. 1990), Gam-42 (5'GCCTTCCCACATCGTTT-3', Manz et al. 1992), Del-495a (5'- AGTTAGCCGGTGCTTST - 3', Loy et al. 2002), Epsy-549 (5'-CAGTGATTCCGAGTAACG-3', Manz et al. 1992) and Arc-94 (5'- TGCGCCACTTAGCTGACA - 3', Moreno et al. 2003). Phylotypes targeted by the different probes are indicated in Table 1.

\section{DNA extraction and 16S rRNA amplification}

DNA was extracted from 3 specimens from $9^{\circ} 50^{\prime} \mathrm{N}$ and 3 from $12^{\circ} 50^{\prime} \mathrm{N}$. Specimens were dissected as follows: at $9^{\circ} 50^{\prime} \mathrm{N}$, gill was extracted from two of the specimens (9-1-Gi and 9-2Gi), while the visceral mass (i.e. the rest of the animal containing the digestive tract and the heart, gonad, digestive gland, liver, and excretory organs), was treated separately (9-1-VM and 9-2-VM). A third specimen (9-3) was treated as a whole. DNA was also extracted from the empty shell of specimen 2 (9-2-Sh). At $12^{\circ} 50^{\prime} \mathrm{N}$, DNA was extracted separately from the gill and visceral mass of three specimens (12-1, 12-2, 12-3). Extractions were performed using the DNA Tissue Kit (Qiagen). A 1500bp fragment of the 16S rRNA-encoding gene was amplified by PCR using primers $27 \mathrm{~F}$ and $1492 \mathrm{R}$, over 32 cycles. Three PCR products were pooled together for each sample, to reduce PCR bias. Fragments were cloned using a TOPO TA Kit (Invitrogen, CA). 11 to 32 clones were successfully sequenced from each sample by GATC Biotech (Table 1). Genes encoding for key enzymes of sulphur oxidation $(\operatorname{apr} A)$ and autotrophic carbon fixation ( $a c l B)$ were sought. Fragments of the aprA gene encoding APS (adenosine 5'-phosphosulfate) reductase and the $a c l B$ gene encoding ATP Citrate Lyase (the key enzyme in reverse tricarboxylic acide (rTCA) cycle) were amplified using primer sets aps1F/aps4R and 
892F/1204R, respectively as described previously and using 32 to 35 PCR cycles (Campbell et al. 2003, Meyer and Kuever 2007). Obtained PCR products were cloned and inserts were sequenced (Table 2).

\section{Gene sequence analyses}

Chromatograms were checked for quality. For each sample, sequences were aligned, and grouped in Operational Taxonomic Units (OTUs) when $>97 \%$ of the nucleotide positions were identical. For the $16 \mathrm{~S}$ rRNA-encoding genes, overall 11 OTUs were present in more than a single sample. Sequences were compared with databases using BLAST (Altschul et al. 1990; Cole et al. 2009), and the 8 OTUs for which full sequences were available were included in a dataset with their best hits and reference sequences, and aligned using SINA Web Aligner (Pruesse et al. 2007). Alignment was manually checked, and phylogenetic relationships were inferred by using the Maximum Likelihood (ML) method. For the reconstruction, a General Time Reversible model, with a Gamma distribution of evolutionary rates among sites was used (5 categories and invariant sites). For aprA and $a c l B$ genes, recovered sequences were compared to the database using BlastX (Table 2). For $a c l B$, best hits and representative sequences were included in a dataset, and phylogenetic reconstruction was based on a 100 aa-long fragment using a ML approach, a JTT model of amino acid substitution and a Gamma distribution of evolutionary rates among sites (tree in Fig. S1). All analyses were conducted using MEGA6 (Tamura et al. 2013).

\section{Stable isotope analysis}

Frozen Cyathermia naticoides $\left(n=4\right.$ for $\delta^{13} \mathrm{C}$ and $\delta^{15} \mathrm{~N}, n=10$ for $\delta^{34} \mathrm{~S}$ for $9^{\circ} 50^{\prime} \mathrm{N}$ and $n=5$, only $\delta^{13} \mathrm{C}$ and $\delta^{15} \mathrm{~N}$, for $12^{\circ} 50^{\prime} \mathrm{N}$ ) were dissected under a dissecting microscope to remove the shell. Specimen tissues were rinsed in distilled water, dried $\left(3\right.$ days, $\left.60^{\circ} \mathrm{C}\right)$ and then reduced into powder. To avoid significant changes in $\delta^{15} \mathrm{~N}$ isotopic composition, no $\mathrm{HCl}$ was used to remove carbonates (Kaehler and Pakhomov 2001). About $1 \mathrm{mg}( \pm 0.1 \mathrm{mg})$ of dried tissues (except $8 \mathrm{mg}$ for sulfur stable isotopes; pool of 10 specimens) were analyzed by a GV IsoPrime (UK) stable isotope mass spectrometer (Iso-Analytical, Crewe, UK). Values of $\delta^{13} \mathrm{C}$, $\delta^{15} \mathrm{~N}$ and $\delta^{34} \mathrm{~S}$ were determined and expressed as relative per-mil (\%o) differences between samples and Pee Dee Belemnite (PDB) for carbon, air $\mathrm{N}_{2}$ for nitrogen and Canyon Diablo Troilite for sulfur according to the following equation:

$\delta(X)=\left\lfloor\left(\frac{R_{\text {sample }}}{R_{\text {standard }}}\right)-1\right\rfloor * 1000$ where $X(\%)$ is ${ }^{13} \mathrm{C},{ }^{15} \mathrm{~N}$ or ${ }^{34} \mathrm{~S}$ abundance and $R$ is the ${ }^{13} \mathrm{C} /{ }^{12} \mathrm{C},{ }^{15} \mathrm{~N} /{ }^{14} \mathrm{~N}$ or ${ }^{34} \mathrm{~S} /{ }^{32} \mathrm{~S}$ ratios. 


\section{Chitinolytic activity assays.}

177 Chitinolytic activity was determined using a modification by Gutowska et al. (2004) of the

178

179

180

181

182

183

184

185

186

187

188

189

190

191

192

193

194

195

196

197

198

199

200

201

202

203

204

205

206

207

208

209

standard procedure of Jeuniaux (1966), which measures the production of N-Acetyl glucosamine (NAG). Five specimens from $12^{\circ} 50^{\prime} \mathrm{N}$ were removed from their shell and ground together in liquid nitrogen. The powder was homogenized in $0.15 \mathrm{M}$ citric acid, $0.3 \mathrm{M}$ $\mathrm{Na}_{2} \mathrm{HPO}_{4}$ buffer ( $\mathrm{pH}=5$ and $\mathrm{pH}=7$ ). The homogenates were then centrifuged at $2000 \mathrm{~g}$ for $10 \mathrm{~min}$ at $4^{\circ} \mathrm{C}$, the supernatants were recovered and assayed for their chitinolytic activity. The standard mixture consisted of 2 vol. of tissues extract, 1 vol. of chitobiase and 1 vol. of chitin suspension $\left(5 \mathrm{mg} \cdot \mathrm{ml}^{-1}\right)$. Two control assays were added, with either the tissues extract or the chitin solution replaced by distilled water. For comparison, assays with commercial Streptomyces griseus chitinase (Sigma C6137) were also conducted in parallel. They were all incubated at $37^{\circ} \mathrm{C}$, and aliquots were taken after $\mathrm{t}=0 \mathrm{~min}, \mathrm{t}=90 \mathrm{~min}$ and $\mathrm{t}=180 \mathrm{~min}$. Chitinolytic reaction was stopped by mixing 1 vol. of the reaction medium with 1 vol. of boiling water. The mix was placed $10 \mathrm{~min}$ at $100^{\circ} \mathrm{C}$, then centrifuged at $2000 \mathrm{~g}$ for $10 \mathrm{~min}$. The supernatants were used for NAG measurements by adding $\mathrm{K}_{2} \mathrm{~B}_{4} \mathrm{O}_{7} 0.8 \mathrm{M}$, and further incubating for $3 \mathrm{~min}$ at $100^{\circ} \mathrm{C}$. p-dimethylaminobenzaldehyde (DMAB) was added and after 20 min at $37^{\circ} \mathrm{C}$, the concentration of NAG released was determined by comparing each sample's absorbance at $585 \mathrm{~nm}$ to NAG standard curves. The activity was expressed as $\mu \mathrm{g}$ of NAG released per gram protein per hour.

\section{$\underline{\text { Results }}$}

\section{Morphology and ultrastructure of gut and gill}

Cyathermia naticoides is a gastropod with a regularly coiled shell (diameter up to $7 \mathrm{~mm}$ ), with a deep notch at basal side of the outer lip. This gastropod possesses a very large bipectinate gill, which occupies most of the anterior part of the animal (Fig. 1a, b). Semi-thin sections revealed an abundant bacterial community associated with the gill (Fig. 1c, d). These gram-negative filamentous bacteria $(0.5$ to $0.6 \mu \mathrm{m}$ in diameter and up to $5.8 \mu \mathrm{m}$ in length,

Fig. 2a, b) were located extracellularly, between the gill filaments, mainly at their base. Some of the bacteria were free in the inter-lamellar space, but many have also been observed trapped in lysosome-like structures in the gill epithelium (see Fig. 1d and 2a), and appeared to undergo different stages of degradation (Fig. 2b). Bacterial colonization and endocytosis occurred on each animal and all sections observed.

The digestive tract contained pieces of Riftia pachyptila tubes (not shown), recognizable by chitin microfibrils organized in parallel bundles with various orientations (Gaill and Shillito 
1995). No bacteria similar to those present on the gill were observed in the gut contents.

\section{Fluorescence microscopy observations}

213 Probes Eub-338 and Arc-94 yielded strong signals in regions of the gill filaments of

214 Cyathermia naticoides from both $9^{\circ} 50^{\prime} \mathrm{N}$ and $12^{\circ} 50^{\prime} \mathrm{N}$ (Fig. 1e, f). Cy-3 labeled probe Epsy215549 yielded weaker signal, but signal-to-noise ratio was greatly improved when letting tissue 216 autofluorescence decrease under the laser for 30 seconds. Signals from the three probes fully 217 overlapped in gills (not shown). Hybridized objects corresponded to thin filamentous bacteria. 218 Parts of the gill filaments were free of bacteria and did not display any signal, suggesting that 219 the distribution of bacteria was not homogeneous (Fig. 1f). Probes Gam-42 and Del-495a did not display any signal in the gills. No FISH signal was observed from the gut epithelium or

\section{Chitinolytic activity}

224 Chitinase activity was assayed on crude extracts from whole specimens. The measured activity (20 $\mu \mathrm{g}$ NAG released $\mathrm{g}^{-1}$ protein $\mathrm{h}^{-1}$ ) was very weak when compared to the reference sample (Streptomyces griseus chitinase, $6500 \mu \mathrm{g}$ NAG released $\mathrm{g}^{-1}$ protein $\mathrm{h}^{-1}$ ). Another gastropod (Lepetodrilus elevatus) found on R. pachyptila tubes was also analyzed for comparison, and showed a two-fold higher activity ( $42 \mu \mathrm{g} \mathrm{NAG} \mathrm{released} \mathrm{g}^{-1}$ protein $\mathrm{h}^{-1}$ ), which was still very weak when compared to S. griseus.

\section{Bacterial communities associated with digestive tract and gill}

232 Out of 295 sequences obtained, $244(83 \%)$ belonged to one of the 11 OTUs (defined as groups of sequences displaying above $97 \%$ identical positions) that were present in more than a single sample (see Table 1). The remaining sequences corresponded to single reads occurring in a single sample. Above $78.0 \%$ of total sequences, and 7 of the 11 OTUs $(94.3 \%$ of the OTUs-assigned sequences) were assigned to the Epsilonproteobacteria. Five of the OTUs $(1,3,8,11,16-p)$, including the 4 most abundant and representing $90 \%$ of the OTUassigned sequences, were present at both sampling sites $9^{\circ} 50^{\prime} \mathrm{N}$ and $12^{\circ} 50^{\prime} \mathrm{N}$.

OTUs 3, 1 and 8 dominated clone libraries, representing 23.1, 20.0 and $19.3 \%$ of the total sequences, respectively (Table 1). OTU 3 was present in gills and visceral mass at $9^{\circ} 50 \mathrm{~N}$ and gill at $12^{\circ} 50 \mathrm{~N}$. This sequence displayed above $98 \%$ identity and was most closely related to sequences from an epibiont of the gastropod Lepetodrilus fucensis, and to various Arcobacter from the EPR (Fig. 3). OTU 1 was present in all samples from $9^{\circ} 50^{\prime} \mathrm{N}$, and in visceral mass samples from two specimens at $12^{\circ} 50^{\prime} \mathrm{N}$. The sequence was closely related and highly similar 
(>98\%) to sequences from bacteria associated with the tube of Ridgeia piscesae on the EPR. The third, OTU 8, was present in gill, visceral mass and shell at all sites and displayed above 98\% identity with several sequences related to the sulfur-oxidizing chemolithotroph Sulfurovum from the Brothers Seamount (Kermadec Arc) and vents.

\section{Functional gene analysis}

Overall 70 aprA sequences were obtained from the visceral mass of three specimens, and none from the gill tissue. Six distinct nucleotide sequences were obtained, 4 of which were related to Gammaproteobacteria and represented above $94 \%$ of total sequences (Table 2). The dominant sequence, clone 761, was $96 \%$ similar (amino acids) to a sequence from an epibiont of the Yeti crab Kiwa hirsuta. Other sequences were similar to a sequence from a bacterium associated with the oligochete Tubificoides benedii and from the tube of the siboglinid annelid Lamellibrachia anaximandri (Table 2).

PCRs on the $a c l B$ gene yielded faint bands from the visceral mass of specimen 9-1 and 9-2-, and from the gills of specimen 9-2. Out of 28 sequenced clones from each of these 3 samples, only 35 good quality sequences were obtained. The majority (24) were from the gill, of which 19 corresponded to a single sequence, clone 765 , and were related to various sequences of Epsilonproteobacteria from hydrothermal vents and to epibionts from the gill chamber of the vent shrimp Rimicaris exoculata (around 98\% amino acid similarity, Table 2 and Fig S1).

\section{Stable isotope composition}

The $\delta^{13} \mathrm{C}$ values of Cyathermia naticoides varied following vent sites, with $-9.0 \%$ o $( \pm 0.3 \%$ ) for $9^{\circ} 50 ' \mathrm{~N}$ and $-10.8 \%$ o $\left( \pm 0.4 \%\right.$ ) for $12^{\circ} 50^{\prime} \mathrm{N}$ (Fig. 4). These stable isotopic ratios of carbon fall after correction of fractionation $\left(1 \%\right.$ for $\delta^{13} \mathrm{C}$ and $3.3 \%$ for $\left.\delta^{15} \mathrm{~N}\right)$ into the range of stable isotopic ratios of carbon of Epsilonproteobacteria (range between -8 and -12\%o; Campbell et al. 2003) (Fig. 4). Regarding $\delta^{15} \mathrm{~N}$, value of both sites was 6.8\%o ( $\pm 0.5 \%$ ). This nitrogen stable isotopic ratio is typical of a primary consumer at vents (between 4 and 8\%o). Isotopic signatures of $\delta^{34} \mathrm{~S}$ measured in a pool of $C$. naticoides $(\mathrm{n}=10)$ was $5.5 \%$.

\section{Discussion}

\section{Grazing vs. filter-feeding}

Gastropods have two main feeding strategies: i.e. grazing, using their radula to rasp various kinds of substrates, or filter feeding, using their gills as a trap to capture and sort particles suspended in seawater. At hydrothermal vents, where the organic matter synthesis relies on chemoautotrophic bacteria, most gastropods appear to feed on free-living bacteria (Bates et al. 
2007b). Up to now, Cyathermia naticoides was inferred to graze on tubeworms bacterial cover, but also to use filter feeding, based on its very large bipectinate gill (Warén and

282 Bouchet 1989). Grazing on tubeworms bacterial cover is congruent with our observations, as we noted the occurrence of Riftia pachyptila tube pieces in the gut content. Conversely, filter feeding on bacteria is not well-supported by our data. The position of the filamentous bacteria, deep between the filaments, and the large number of endocytosed and lysed bacteria advocates for a stronger association than a classic trapping through filter feeding mechanism for transport to the gut. Nevertheless, filter feeding on particulate organic matter cannot be discarded.

\section{A diet based on bacteria}

Despite R. pachyptila tube pieces, which contain up to 25\% of chitin (Ravaux et al. 1998), are rasped and ingested by $C$. naticoides, a weak chitinolytic activity was measured for this species, when compared to the reference chitinase of Streptomyces griseus, or to values obtained for chitin degrading animals, such as fishes feeding on crustaceans (Gutowska et al. 2004). This suggest a minor nutritional input of chitin and that $C$. naticoides rather grazes on R. pachyptila tubes for feeding either on proteins contained therein (representing $37-41 \%$ of the tube, Ravaux et al. 1998) or on the bacterial biofilm. López-García and collaborators (2002) observed dense microbial populations on $R$. pachyptila tubes, with very diverse 16S rRNA phylotypes, belonging mostly to Epsilon-, but also to Delta-, Alpha- and Gammaproteobacteria. Interestingly, among our recovered bacterial phylotypes, OTUs 1 and 11 are closely related to several sequences from the tubes of Ridgeia piscesae and Riftia pachyptila (Fig. 3; Forget and Juniper 2013; López-García et al. 2002). These could be bacteria ingested alongside with tube fragments. Indeed, of the 59 sequences of OTU 1 for example, 36 were from the visceral mass of $C$. naticoides (3.4 to $63 \%$ of the sequences depending on the sample). This sequence displays 5 and 1 mismatches with FISH probes Arc94 and Epsy549 and thus does not hybridize with them. It is thus surely not the sequence from the bacteria located in the gills, which respond to both probes. Sequences encoding APS reductase were successfully amplified from the visceral mass of all tested specimens. Related sequences were typically associated with the tube or cuticle of protostomes. These might again correspond to sequences of bacteria ingested with scrapings of tubes. The dense colonies of filamentous Epsilonproteobacteria observed on $C$. naticoides gill surface could be another nutritional pathway. Many are indeed endocytosed within lysosomes, arguing for a internal digestion of bacteria in the gill epithelium.

314 Vent gastropods at hydrothermal vents are considered as primary consumers feeding both on 315 free-living bacteria of different origins but also on particulate organic matter (Limen et al. 
2007), resulting in a range of stable isotopes nitrogen ratio between 4 and $8 \%$ (Bergquist et al. 2007; Limén et al. 2007; Gaudron et al. 2012), which includes our values for Cyathermia naticoides. Several species of Lepetodrilus are known to be also primary consumers (heterotrophic) such as L. elevatus, L. pustulosus and L. ovalis, displaying the same range of stable isotopic nitrogen values (Fig. 4). However L. fucencis known to harbor symbiotic bacteria within its gills also has a similar stable isotopic nitrogen value (7\%, Bates et al. 2011), as well as others larger symbiotic gastropods (Alviniconcha spp) harboring Epsilonproteobacteria (Fig. 4), meaning that heterotrophic and symbiotic diet may co-occur in $C$. naticoides and cannot be easily distinguished based on nitrogen isotopes. In the previously studied symbioses involving Epsilonproteobacteria, a trophic role has been suggested based on carbon stable isotope signatures of hosts $\left(\delta^{13} \mathrm{C}\right.$ values between -11 and $10.7 \%$ for $A$. aff hessleri ; -12.8 and $-11.2 \%$ for Alvinella pompejana and -12 to $-10 \%$ for Rimicaris exoculata, Suzuki et al. 2005b; Desbruyères et al. 1998; Polz et al. 1998). These values indeed fall within the range of typical values measured in Epsilonproteobacteria which use the reverse TCA cycle for autotrophic carbon fixation (-12 to -8\%, Campbell et al. 2006; Sievert and Vetriani 2012). Similar values are measured in C. naticoides $(-10.84 \pm 0.58 \%$; Fig. 4), suggesting that similar bacteria may significantly contribute to the hosts diet, either those grazed on tubes or those endocyted in the gill. López-García and collaborators (2002) identified that most bacteria (68\%) present on $R$. pachyptila tube surface belonged to the Epsilonproteobacteria ( $\delta^{13} \mathrm{C}$ value for scrappings from $R$. pachyptila tubes are $-12,5 \%$ ). In Cyathermia, this is further supported by the identification of ATP Citrate Lyase-encoding genes from the visceral mass of specimens which confirm the presence of rTCA. On the other hand, a single dominant ATP Citrate Lyase sequence is also identified from gill-associated bacteria, which supports the hypothesis of a significant contribution of the gill bacteria to the host carbon nutrition. The next step will be to quantify the respective roles of gill-associated versus ingested bacteria. The vast majority of symbiotic bacteria described at present in molluscs are chemoautotrophic sulfur-oxidizing bacteria. The $\delta^{34} \mathrm{~S}$ value of an animal indicates the origin of the assimilated sulfur. Marine invertebrates for which the sulfur source comes from chemosynthetic sulfuroxidation have values lower than $5 \%$. $\delta^{34} \mathrm{~S}$ of $C$. naticoides (5\%) is at the upper end normally measured into thiotrophic metazoans, which is between -25 to 5\% (Vetter and Fry 1998), allowing to suppose that some sulfur absorbed by the animal comes from chemosynthetic sulfur-oxidizers. If evidence for thiotrophic metabolism has been shown through sequencing of APS reductase in the visceral mass (possibly coming from the bacteria 
in the gut, rasped on $R$. pachyptila tubes), no positive PCR result was obtained from gills. We cannot thus confirm the thiotrophic metabolism of gill-associated bacteria.

\section{Symbiosis}

A widespread feeding strategy at hydrothermal vents is to obtain organic carbon through symbiotic associations. Among molluscs, symbioses are well known and described in large species, such as the mussels and clams (Mytilidae and Vesicomyidea, Dubilier et al. 2008) or the large gastropods Ifremeria nautilei and Alviniconcha hessleri (Provannidae, Borowski et al. 2002; Suzuki et al. 2005a, b). In all these symbioses, sulfide-oxidizing

Gammaproteobacterial symbionts are endosymbionts, occurring within the host tissues in gill epithelial bacteriocytes. The hosts are fuelled by by-products of bacterial metabolism (ultimately relying on sulfide oxidation) or intracellular bacterial digestion (Bates 2007b). Here we described the occurrence of a dense population of filamentous bacterial located extracellularly at the base of the gill filaments. Some are free in the inter-lamellar space, but many have also been observed trapped in lysosome-like structures, in the gill epithelium. At hydrothermal vents, epibiotic symbioses have been described in only a few groups: Ciliophora (Kouris et al. 2007), annelids (Alvinella pompejana, Haddad et al. 1995; Cary et al. 1997; Bright and Giere 2005) and crustaceans (Rimicaris exoculata, Segonzac et al. 1993; Zbinden et al. 2008; Petersen et al. 2010; the galatheid crabs Kiwa hirsuta (Macpherson et al. 2005; Goffredi et al. 2008), Kiwa puravida (Thurber et al. 2011), and Shinkaia crosnieri (Miyake et al. 2007). In Molluscs, only very few examples are known : in Aplacophora (Katz et al. 2006) and in Gastropoda (Lepetodrilus fucensis, Bates 2007a, b). The kind of symbiosis described in L. fucensis is the closest to what we observed in Cyathermia naticoides, with a few exceptions. L. fucensis hosts dense colonies of filamentous bacteria on its gill surface, where bacteria are found partially embedded in the host's gill epithelium and extend into the fluid circulating between the lamellae (de Burgh and Singla 1894 ; Bates et al. 2007a, b). Frequent endocytosis was observed in the epithelium (de Burgh and Singla 1984). Observed residual bodies of lysosome-like organelles, with concentric membrane stacks, mirror our observations. The main difference between L. fucensis and C. naticoides is that most abundant L. fucensis epibionts are Gammaproteobacteria (Bates et al. 2011), and those of $C$. naticoides belong to Epsilonproteobacteria. Furthermore, stables isotopes analyses $\left(\delta^{13} \mathrm{C}=\right.$ 19.5 to $-14.8 \%$ and $\delta^{15} \mathrm{~N}=2.5$ to $5 \%$ ) situate L. fucensis within a group of known deposit feeding invertebrates at the Juan de Fuca Ridge vents (Fox et al. 2002), whereas Cyathermia values fall within the range of typical values measured in Epsilonproteobacteria, and in 
organisms living in symbiosis with these bacteria (-12 to $-8 \%$, Campbell et al. 2006; Sievert and Vetriani 2012).

As suggested by de Burgh and Singla (1984) and Bates (2007a), there are 3 ways in which the gill bacteria may contribute to the organic carbon of the host : 1) the bacteria may be farmed and ingested; 2) dissolved organic molecules, byproduct of the bacterial metabolism, may pass from the bacteria to the host through the epithelium, as it was suggested for Alvinella pompejana and evidenced for the shrimp Rimicaris exoculata and its epibionts (Ponsard et al. 2013); 3) bacteria may be endocytosed in the gill epithelium and digested within lysosomes. For L. fucensis, Bates (2007b) argues that endocytosis of bacteria by the gill epithelium followed by lysosomal digestion (de Burgh and Singla 1984) may not be an important feeding mechanism. In our case, the huge number of lysosome-like structures observed, with bacteria at different stages of degradation conversely rather advocates for the third hypothesis. Nevertheless, additional contribution by the two other ways cannot be discarded.

These gill bacteria likely correspond to our OTU 3, which is the predominantly associated with gill samples. Indeed, 43 of the 68 sequences were from gill samples, representing between 22 to $100 \%$ of sequences in the various gill samples. Besides, OTU 3 was present in gills of all specimens at both sites, and far less abundant in visceral mass samples, representing only from 0 to $22 \%$ of the sequences. Futhermore, it responds to both Arc-94 and Epsy-549 probes, as do gill bacteria observed using FISH. Finally, it is closely related to one of the documented gill epibionts of Lepetodrilus fucensis. OTU 3 might be a widespread epibiont of gastropod gills.

The third most abundant OTU identified in our clone libraries, namely OTU 8, related to Sulfurovum also responds to both FISH probes. However, only 10 of the 57 recovered sequences were from gill tissue, representing 0 to $29 \%$ of sequences depending on gill sample, while 14 were found on the shell analyzed (45\%) and 33 in the visceral mass. Closest relatives do not include any reported symbiont. This bacterium is thus most probably an environmental bacterium, although this cannot be ascertained using FISH probes from this study.

As seen above, the large majority of the mollusc-associated symbionts from chemosynthetic environments are Gammaproteobacteria (in the Thyasiridae, Lucinidae, Solemyidae, Vesicomyidae, Mytilidae, and some Provanidae). But recently (Suzuki et al. 2005a, 2005b), Epsilonproteobacteria were described as symbionts (and as endosymbionts) in some species of Provannidae (Alviniconcha sp.). A. hessleri from the Mariana Trough, Alviniconcha sp. type 1 from Manus Basin and Fiji, and Alviniconcha sp. from Lau Basin harbors sulfuroxidizing chemoautotrophic Gammaproteobacterial endosymbionts that mediate the Calvin- 
Benson cycle to fix $\mathrm{CO}_{2}$. Whereas Alviniconcha aff. hessleri from the Central Indian Ridge and Alviniconcha sp. type 2 from Manus Basin and Fiji harbors chemoautotrophic Epsilonproteobacterial endosymbionts that mediate the reductive tricarboxylic acid (rTCA) cycle for $\mathrm{CO}_{2}$ fixation (Urakawa et al. 2005; Suzuki et al. 2006). A fragment of the gene encoding ATP Citrate Lyase was identified in the gill and visceral mass of $C$. naticoides. In particular, the most abundant sequence in the gills was related to sequences from various vent bacteria including gill epibionts of the vent shrimp $R$. exoculata. This advocates for the presence of this pathway in gills of $C$. naticoides. This finding is congruent with the dominance of Epsilonproteobacteria in the gill, and it is possible that the dominant $a c l B$ sequence (clone 765) is indeed associated with the dominant $16 \mathrm{~S}$ rRNA OTU 3, or one of the other dominant gill-associated phylotypes.

Symbiotic association with filamentous Epsilonproteobacteria have been described, but mostly as ectosymbioses, as in the crustaceans $R$. exoculata, K. hirsuta, K. puravida or $S$. crosnieri and in the annelid A. pompejana (see references above). The C. naticoides symbiosis described here thus represents a unusual type of association in the long list of symbiosis within Molluscs, with Epsilonproteobacteria as ectosymbionts being the first exemple of this combination in molluscs, to our knowledge.

\section{Epsilon- versus Gammaproteobacteria : an issue with temperature ?}

Urakawa and collaborators (2005) suggest that thermal gradient may affect the acquisition and evolutionary selection of either Epsilon- or Gammaproteobacterial symbionts. Vent hosts harboring Epsilonproteobacterial symbionts such as shrimps or polychetes, usually live at higher temperatures than those harboring Gammaproteobacteria, such as clams or vestimentiferans. Indeed, the two Provannidae gastropods, Alviniconcha spp. and Ifremeria nautilei, studied by Urakawa, co-occur at the same sites in the Manus Basin, the former harboring Epsilonproteobacterial symbionts living at higher temperatures than I. nautilei which harbors Gammaproteobacteria. This could be congruent with our example, as $C$. naticoides that lives on tubes of Riftia pachyptila may in fact live in a warmer microhabitat that the tubeworm itself and its Gammaproteobacterial endosymbionts, the latter being protected by the chitinous tube. C. naticoides lives in sympatry with another small gastropod, Lepetodrilus elevatus on the tube of $R$. pachyptila, where a vertical microzonation has been observed. Individuals of $C$. naticoides cluster at the base of the tubes, where temperatures up to $25^{\circ} \mathrm{C}$ were measured (Sarradin et al. 1998), whereas L. elevatus rather graze higher up the tubes (P. Tyler, pers. obs. cited in Mills et al. 2007), where temperatures ranged between 1.6 and $10^{\circ} \mathrm{C}$ (Sarradin et al. 1998). So C. naticoides is associated with the warmer part of $R$. 
454

455

456

457

458

459

460

461

462

463

464

465

466

467

468

469

470

471

472

473

474

475

476

477

478

479

480

481

482

483

484

485

486

487

488

489

pachyptila tube, and is also sometimes found among A. pompejana tubes (Desbruyères et al. 2006; Mills et al. 2007), which live on the chimney walls at even higher temperatures (up to $50^{\circ} \mathrm{C}$ was measured at $2-5 \mathrm{~cm}$ within the tube assemblages, Le Bris et al. 2005). Temperature can also be put forward to explain the different bacterial partners in C. naticoides (Epsilonproteobacteria ) et L. fucensis (Gammaproteobacteria ) ectosymbioses. Indeed Lepetodrilus fucensis was reported (Bates et al. 2005) to be abundant in fluids with temperature between 4 and $10^{\circ} \mathrm{C}$, and to be absent where maximum fluid temperature reached $18^{\circ} \mathrm{C}$. Although precise temperatures have not been reported in literarture, $C$. naticoides is probably exposed to temperatures exceeding $20^{\circ} \mathrm{C}$ in the habitats its occupies (base of $R$. pachyptila tubes or A. pompejana clumps).

This selection of either Epsilon- or Gammaproteobacterial symbionts which seem to be affected by temperature, could also be linked to oxygen availability (both being negatively correlated). Sulfur metabolism pathways are indeed not the same in Epsilon- and Gammaproteobacteria. Both of the pathways used by deep-sea hydrothermal Gammaproteobacteria (the reverse sulfate reduction and the Sox multienzyme system ) require $\mathrm{O}_{2}$ as a terminal electron acceptor in most cases. This indicates that a relatively $\mathrm{O}_{2}-$ depleted environment is less suitable for their growth (Yamamoto and Takai, 2011). Thus, it is predicted that the metabolically habitable niches for deep-sea chemoautotrophic Gammaproteobacteria strictly require co-existence of reduced sulfur compounds and $\mathrm{O}_{2}$. Besides oxygen, some Epsilonproteobacteria are also able to use sulfur compounds as electron acceptors (Yamamoto and Takai, 2011), which may allow them to tolerate and colonize $\mathrm{O}_{2}$-depleted and warmer niches within the mixing zone, closer to the reducing hydrothermal fluid.

\section{Conclusion}

Cyathermia naticoides harbors dense populations of filamentous Epsilonproteobacteria in its gill which may contribute to their nutrition through intracellular digestion by gill cells. OTU 3 was identified as a probable candidate dominant gill bacterium. Yet, the diet could be mixotrophic, an additional food source being the bacteria grazed on $R$. pachyptila tubes.

OTUs 1 and 11 identified here are likely siboglinid tube-associated Epsilonproteobacteria that may be significant food sources on this route. Novel for molluscs by the combination of the location (ectosymbionts) and bacterial phylotype (Epsilonproteobacteria) encountered and the feeding mechanism, the symbiosis of $C$. naticoides represents an unusual type of association in the already long list of molluscan symbioses, of which more await characterization in particular in smaller-sized species. 


\section{Acknowledgements}

We thank the chief scientists, N. Le Bris and F. Lallier, as well as the captain and crew of the

RV Atalante and the 'Nautile' team for their help during the Mescal 2010 cruise. We thank E.

494

495

496

497

498

499

500

501

502

503

504

505

506

507

508

509

510

511

512

513

514

515

516

517

518

519

520

521

522

523

524

525

526

527

528

529

530

531

532

533

534

535

536

537

538

539

540

541

Thiébaut and Marjolaine Matabos for their help in sorting an identifying the various

gastropods sampled. TEM was performed at the 'Plateforme de Microscopie Electronique'

(MNHN) with the help of C. Djediat. Work was funded through UPMC and CNRS.

\section{References}

Altschul S, Gish W, Miller W, Myers E, Lipman D (1990) Basic local alignment search tool. J Mol Biol 215: 403-410

Amann R, Binder B, Olson R, Chisholm S, Devereux R, Stahl D (1990) Combination of 16S rRNAtargeted oligonucleotide probes with flow cytometry for analysing mixed microbial populations. Appl Env Microbiol 56: 1919-1925

Bates A (2007a) Feeding strategy, morphological specialisation and presence of bacterial episymbionts in lepetodrilid gastropods from hydrothermal vents. Mar Ecol Prog Ser 347: 87-99

Bates A (2007b) Persistence, morphology, and nutritional state of a gastropod hosted bacterial symbiosis in different levels of hydrothermal vent flux. Mar Biol 152: 557-568

Bates A, Tunnicliffe V, Lee R (2005) Role of thermal conditions in habitat selection by hydrothermal vent gastropods. Mar Ecol Prog Ser 305: 1-15

Bates A, Harmer T, Roeselers G, Cavanaugh C (2011) Phylogenetic characterization of episymbiotic bacteria hosted by a hydrothermal vent limpet (Lepetodrilidae, Vetigastropoda). Biol Bull 220: $118-127$

Beinart R, Sanders J, Faure B, Sylva S, Lee R, Becker E, Gartman A, Luther III G, Seewald J, Fisher C, Girguis P (2013) Evidence for the role of endosymbionts in regional-scale habitat partitioning by hydrothermal vent symbioses. PNAS 109 (47): doi: 10.1073/pnas.1202690109

Bergquist D, Eckner J, Urcuyo I, Cordes E, Hourdez S, Macko S, Fisher C (2007) Using stable isotopes and quantitative community characteristics to determine a local hydrothermal vent food web. Mar Ecol Prog Ser 330: 49-65

Borowski C, Giere O, Krieger J, Amann R, Dubilier N (2002) New aspects of the symbiosis in the provannid snail Ifremeria nautilei from the North Fiji Back Arc Basin. Cah Biol Mar 43: 321-324

Bright M, Giere O (2005) Microbial symbiosis in Annelida. Symbiosis 38: 1-45

Campbell B, Stein J, Cary S (2003) Evidence of chemolithoautotrophy in the bacterial community associated with Alvinella pompejana, a hydrothermal vent polychaete. Appl Environ Microbiol 69 (9): 5070-5078

Campbell B, Engel A, Porter M, Takai K (2006) The versatile $\varepsilon$-proteobacteria: Key players in sulphidic habitats. Nat Rev Microbiol 4: 458-468

Cary S, Cottrell M, Stein J, Camacho F, Desbruyères D (1997) Molecular identification and localization of filamentous symbiotic bacteria associated with the hydrothermal vent Annelid Alvinella pompejana. Appl Environ Microbiol 63: 1124-1130

Cole J, Wang Q, Cardenas E, Fish J, Chai B, Farris R, Kulam-Mohideen A, McGarrell D, Marsh T, Garrity G, Tiedje J (2009) The ribosomal database project: improved alignments and new toolds for rRNA analysis. Nucleic Acids Res 37: 141-145

de Burgh M, Singla C (1984) Bacterial colonization and endocytosis on the gill of a new limpet species from a hydrothermal vent. Mar Biol 84: 1-6

Desbruyères D, Chevaldonné P, Alayse A, Jollivet D, Lallier F, Jouin-Toulmond C, Zal F, Sarradin P, Cosson R, Caprais J, Arndt C, O'Brien J, Guezennec J, Hourdez S, Riso R, Gaill F, Laubier L, Toulmond A (1998) Biology and ecology of the "Pompeii worm" (Alvinella pompejana Desbruyères and Laubier), a normal dwellerof an extreme deep-sea environment: A synthesis of current knowledge and recent developments. Deep-Sea Res Pt II 45: 383-422

Desbruyères D, Segonzac M, Bright M (2006) Handbook of deep-sea hydrothermal vent fauna. Second completely revised edition. Biologiezentrum der Oberösterreichischen Landesmuseen 
Dubilier N, Bergin C, Lott C (2008) Symbiotic diversity in marine animals : the art of harnessing chemosynthesis. Nat Rev Microbiol 6: 725-740

Felbeck H, Somero G (1982) Primary production in deep-sea hydrothermal vent organisms: roles of sulfide-oxidizing bacteria. Trends in Biochemical Science 7 (6): 201-204

Forget N, Juniper K (2013) Free-living bacterial communities associated with tubeworm (Ridgeia piscesae) aggregations in contrasting diffuse flow hydrothermal vent habitats at the Main Endeavour Field, Juan de Fuca Ridge. MicrobiologyOpen 2(2): 259-275

Fox M, Juniper S, Vali H (2002) Chemoautotrophy as a possible nutritional source in the hydrothermal vent limpet Lepetodrilus fucensis. Cah Biol Mar 43: 371-376

Gaill F, Shillito B (1995) Chitin from deep sea hydrothermal vent organisms. In: Giraud-Guille M, André J (eds) Chitin in Life Science, Lyon, pp 88-96

Gaudron SM, Lefebvre S, Nunes Jorge A, Gaill F, Pradillon F (2012) Spatial and temporal variations in food web structure from newly-opened habitat at hydrothermal vents. Mar Env Res 77: 129-140

Goffredi S, Waren A, Orphan V, Van Dover C, Vriejenhoek R (2004) Novel forms of structural integration between microbes and a hydrothermal vent gastropod from the Indian Ocean. Appl Environ Microbiol 70 (5): 3082-3090

Goffredi S, Jones W, Ehrlich H, Springer A, Vriejenhoek C (2008) Epibiotic bacteria associated with the recently discovered Yeti crab, Kiwa hirsuta. Environ Microbiol 10(10): 2623-2634

Gutowska M, Drazen J, Robison B (2004) Digestive chitinolytic activity in marine fishes of Monterey Bay, California. Comp Biochem Physiol, Part A 139: 351-358

Haddad A, Camacho F, Durand P, Cary S (1995) Phylogenetic characterization of the epibiotic bacteria associated with the hydrothermal vent polychaete Alvinella pompejana. 61 (5) Appl Environ Microbiol: 1679-1687

Henry M, Childress J, Figueroa D (2008) Metabolic rates and thermal tolerances of chemoautotrophic symbioses from Lau Basin hydrothermal vents and their implications for species distributions. Deep-Sea Res Pt I 55: 679-695

Jeuniaux C (1966) Chitinases. Methods Enzymol 8: 644-650

Kaehler S, Pakhomov E (2001) Effects of storage and preservation on the delta C-13 and delta N-15 signatures of selected marine organisms. Mar Ecol Prog Ser 219: 299-304

Katz S, Cavanaugh C, Bright M (2006) Symbiosis of epi- and endocuticular bacteria with Helicoradomenia spp. (Mollusca, Aplacophora, Solenogastres) from deep-sea hydrothermal vents. Mar Ecol Prog Ser 320: 89-99

Kohn A (1983) Feeding biology of Gastropods. In: Wilbur KM (ed) The Mollusca. Academic Press, New York, pp 1-63

Kouris A, Juniper K, Frebourg G, Gaill F (2007) Protozoan-bacterial symbiosis in a deep- sea hydrothermal vent folliculinid ciliate (Folliculinopsis sp.) from the Juan de Fuca Ridge. Mar Ecol 28: 63-71

Le Bris N, Zbinden M, Gaill F (2005) Processes controlling the physico-chemical micro-environments associated with Pompeii worms. Deep-sea Res Pt I 52: 1071-1083

Levesque C, Juniper K, Limén H (2006) Spatial organization of food webs along habitat gradients at deep-sea hydrothermal vents on Axial Volcano, Northeast Pacific. Deep-Sea Res Pt I 53: 726-739

Limén H, Levesque C, Juniper K (2007) POM in macro-/meiofaunal food webs associated with three flow regimes at deep-sea hydrothermal vents on Axial Volcano, Juan de Fuca Ridge. Mar Biol 153: 129-139

López-García P, Gaill F, Moreira D (2002) Wide bacterial diversity associated with tubes of the vent worm Riftia pachyptila. Environ Microbiol 4(4): 204-215

Loy A, Lehner A, Lee N, Adamczyk J, Meier H, Ernst J, Schleifer K, Wagner M (2002) Oligonucleotide microarray for 16S rRNA gene-based detection of all recognized lineages of sulfate-reducing prokaryotes in the environment. Appl Env Microbiol 68: 5064-5081

MacPherson E, Jones W, Segonzac M (2005) A new lobster family of Galatheoidea (Crustacea, Decapoda, Anomura) from the hydrothermal vents of the Pacific-Antarctic Ridge. Zoosystema 27(4): 709-722

Manz W, Amann R, Wagner M, Schleifer K (1992) Phylogenetic oligodeoxynucleotide probes for the major subclasses of Proteobacteria: problems and solutions. Syst Appl Microbiol 15: 593-600

Meyer B, Kuever J (2007) Phylogeny of the alpha and beta subunits of the dissimilatory adenosine-5'phosphosulfate (APS) reductas from sulfate-reducing prokaryotes - origin and evoltuion of the dissimilatory sulfate-reduction pathway. Microbiology 153: 2026-2044

Mills S, Mullineaux L, Tyler P (2007) Habitat associations in gastropod species at East Pacific Rise 
hydrothermal vents $\left(9^{\circ} 50^{\prime} \mathrm{N}\right)$. Biol Bull 212: 185-194

Miyake H, Kitada M, Tsuchida S, Okuyama Y, Nakamura K (2007) Ecological aspects of hydrothermal vent animals in captivity at atmospheric pressure. Mar Ecol 28: 86-92

Moreno Y, Botella S, Alonso J, Ferrús M, Hernández M, Hernández J (2003) Specific Detection of Arcobacter and Campylobacter Strains in Water and Sewage by PCR and Fluorescent In Situ Hybridization. Appl Environ Microbiol 69: 1181-1186

Petersen J, Ramette A, Lott C, Cambon-Bonavita M-A, Zbinden M, Dubilier N (2010) Dual symbiosis of the vent shrimp Rimicaris exoculata with filamentous gamma- and epsilonproteobacteria at four Mid-Atlantic Ridge hydrothermal vent fields. Environ Microbiol 12(8): 2204-2218

Polz M, Robinson J, Cavanaugh C, Van Dover C (1998) Trophic ecology of massive shrimp aggregations at a mid-Atlantic Ridge hydrothermal vent site. Limnol Oceanogr 43(7): 1631-1638

Ponsard J, Cambon-Bonavita M-A, Zbinden M, Lepoint G, Joassin A, Corbari L, Shillito B, Durand L, Cueff-Gauchard V, Compère P (2013) Inorganic carbon fixation by chemosynthetic ectosymbionts and nutritional transfers to the hydrothermal vent host-shrimp, Rimicaris exoculata. ISME Journal 7: 96-109

Pruesse E, Quast C, Knittel K, Fuchs B, Ludwig W, Peplies J, Glöckner F (2007) SILVA: a comprehensive online resource for quality checked and aligned ribosomal RNA sequence data compatible with ARB. Nucleic Acids Res 35: 7188-7196

Ravaux J, Shillito B, Gaill F, Gay L, Voss-Foucart M-F, Childress J (1998) Tubes synthesis and growth process in the hydrothermal vent tube-worm Riftia pachyptila. Cah Biol Mar 39: 325-326

Saito H, Hashimoto J (2010) Characteristics of the Fatty Acid Composition of a Deep-Sea Vent Gastropod, Ifremeria nautilei. Lipids 45: 537-548

Sarradin P, Caprais J, Briand P, Gaill F, Shillito B, Desbruyères D (1998) Chemical and thermal description of the environment of the Genesis hydrothermal vent community ( $\left.13^{\circ} \mathrm{N}, \mathrm{EPR}\right)$. Cah Biol Mar 39: 159-167

Sasaki T, Warén A, Kano Y, Okutani T, Fujikura K (2010) Gastropods from recent hot vents and cold seeps: systematics, diversity and life strategies. In: Kiel S (ed) The Vent and Seep Biota. Springer Science

Segonzac M, de Saint-Laurent M, Casanova B (1993) L'énigme du comportement trophique des crevettes Alvinocarididae des sites hydrothermaux de la dorsale médio-atlantique. Cah Biol Mar 34: 535-571

Sievert S, Vetriani C (2012) Chemoautotrophy at Deep-Sea Vents: Past, Present, and Future. Oceanography 25(1): 218-233

Suzuki Y, Sasaki T, Suzuki M, Tsuchida S, Nealson K, Horikoshi K (2005a) Molecular phylogenetic and isotopic evidence of two lineages of chemoautotrophic endosymbionts distinct at the subdivision level harbored in one host-animal type: the genus Alviniconcha (Gastropoda: Provannidae). FEMS Microbiol Ecol 249: 105-112

Suzuki Y, Sasaki T, Suzuki M, Nogi Y, Miwa T, Takai K, Nealson K, Horikoshi K (2005b) Novel chemoautotrophic endosymbiosis between a member of the epsilon-proteobacteria and the hydrothermal-vent gastropod Alviniconcha aff. hessleri (Gastropoda: Provannidae) from the Indian Ocean. Appl Environ Microbiol 71(9): 5440-5450

Suzuki Y, Kojima S, Sasaki T, Suzuki M, Utsumi T, Watanabe H, Urakawa H, Tsuchida S, Nunoura T, Hirayama H, Takai K, Nealson K, Horikoshi K (2006) Host-symbiont relationships in hydrothermal vent gastropods of the genus Alviniconcha from the southwest Pacific. Appl Environ Microbiol 72 (2): 1388-1393

Tamura K, Stecher G, Peterson D, Filipski A, Kumar S (2013) MEGA6: Molecular Evolutionary Genetics Analysis version 6.0. Mol Biol Evol 30: 2725-2729

Thurber A, Jones W, Schnabel K (2011) Dancing for Food in the Deep Sea: Bacterial Farming by a New Species of Yeti Crab. PLoS One 6(11): e26243. doi:26210.21371/journal.pone.0026243

Urakawa H, Dubilier N, Fujiwara Y, Cunningham D, Kojima S, Stahl D (2005) Hydrothermal vent gastropods from the same family (Provannidae) harbour epsilon - and gamma -proteobacterial endosymbionts. Environ Microbiol 7(5): 750-754

Vetter R, Fry B (1998) Sulfur contents and sulfur-isotope compositions of thiotrophic symbioses in bivalve molluscs and vestimentiferan worms. Mar Biol 132: 453-460

Warén A, Bouchet P (1989) New gastropods from East Pacific hydrothermal vents. Zool Scr 18 (1): 67-102

Warén A, Bouchet P, von Cosel R (2006) Cyathermia naticoides Warèn \& Bouchet, 1989. In: Desbruyères D, Segonzac M, Bright M (eds) Handbook of deep-sea hydrothermal vent fauna. 
Denisia 18, pp 104

Windoffer R, Giere O (1997) Symbiosis of the Hydrothermal Vent Gastropod Ifremeria nautilei

(Provannidae) With Endobacteria - Structural Analyses and Ecological Considerations.193: 381392

Yamamoto M, Takai K (2011) Sulfur metabolisms in epsilon- and gamma-Proteobacteria in deep-sea hydrothermal fields. Fontiers in Microbiology 2: doi: 10.3389/fmicb.2011.00192

Zbinden M, Shillito B, Le Bris N, De Vilardi de Montlaur C, Roussel E, Guyot F, Gaill F, CambonBonavita M-A (2008) New insights on the metabolic diversity among the epibiotic microbial community of the hydrothermal shrimp Rimicaris exoculata. J Exp Mar Biol Ecol 159 (2): 131-140

Zbinden M, Pailleret M, Ravaux J, Gaudron S, Hoyoux C, Lorion J, Halary S, Warén A, Duperron S (2010) Bacterial communities associated with the wood-feeding gastropod Pectinodonta sp. (Patellogastropoda,Mollusca). FEMS Microbiol Ecol 74: 450-463

Ethical standards

The authors declare that the experiments comply with the current laws of the country they were performed (France).

The authors declare that they have no conflict of interest.

\section{$\underline{\text { Figure Legends }}$}

Fig. 1 Cyathermia naticoides ctenidium. a) Specimen outside its shell showing the extansion of the ctenidium (ct). b) Semi-thin section of the ctenidium. c) Basal part of the gill filaments showing the accumulation of bacteria (b) between the gill filaments (gf) and in lysosome-like structure (ly). d) Close-up of bacteria in the inter-filament space (ifs) and in lysosome-like structure (ly). e) Transverse section through the gill, displaying bacterial filaments in white, hybridized with the FISH probe Arc-94. f) Transverse section through the gill displaying animal cells (DAPI-labelled nuclei in blue) and bacteria labelled with probes Eur-338 (Cy3, red) and Arc-94 (Cy5, green), overlying signals resulting in a yellow color. Scale bars : $a=1$ $\mathrm{mm}, \mathrm{b}=100 \mu \mathrm{m}, \mathrm{c}=20 \mu \mathrm{m}, \mathrm{d}=10 \mu \mathrm{m}, \mathrm{e}=50 \mu \mathrm{m}, \mathrm{f}=100 \mu \mathrm{m}$

Fig. 2 Transmission electron micrographs of the gill (A, B) of C. naticoides. a) Bacteria are endocyted in the gill epithelium and $\mathbf{b}$ ) progressively degraded. Scale bars : $a, b=2,5 \mu \mathrm{m}$ Fig 3 Phylogenetic tree based on the analysis of 16S rRNA-encoding gene sequences. The tree with the highest log likelihood (-13800) is shown. The percentage of trees in which the associated taxa clustered together is shown next to the branches. Scale bar represents the number of substitutions per site. Full (>1400 bp) sequences from this study appear in bold and an asterisk indicates an OTU that is present at both $9^{\circ} 50^{\prime} \mathrm{N}$ and $12^{\circ} 50^{\prime} \mathrm{N}$. Sequences corresponding to confirmed metazoan symbionts or epibionts are underlined. All positions with less than $95 \%$ site coverage were eliminated. There were a total of 1302 positions in the final dataset, and partial sequences were excluded 
Fig. $4 \delta^{13} \mathrm{C}$ and $\delta^{15} \mathrm{~N}$ values of Cyathermia naticoides and other heterotrophic and symbiotic vent gastropods. Triangle up are isotopic ratios of Cyathermia naticoides, with dark blue symbols, those sampled at EPR $9^{\circ} 50^{\prime} \mathrm{N}\left(9^{\circ}\right)$ and light blue symbols, those sampled at EPR $12^{\circ} 50^{\prime} \mathrm{N}\left(13^{\circ}\right)$. Triangle down, displayed previous isotopic values respectively, after correction using trophic step fraction of $1.0 \%$ for $\delta^{13} \mathrm{C}$ and $3.3 \%$ for $\delta^{15} \mathrm{~N}$. The rectangle with dashed lines represents the stable isotopes ratios of $\varepsilon$-proteobacteria from Campbell et al. (2003). $\delta^{13} \mathrm{C}$ and $\delta^{15} \mathrm{~N}$ values of other gastropods are from: Levesque et al. (2006) for Lepetodrilus fucencis; Gaudron et al. (in revision) for L. elevatus $\left(9^{\circ}\right.$ and $\left.13^{\circ}\right)$, L. pustulosus, L. ovalis and Eulepetopsis vitrea; Henry et al. (2008) for Ifremeria nautilei; Goffredi et al. (2004) for the Scaly snail; Beinart et al. (2013) for $\delta^{13} \mathrm{C}$ for Alviniconcha hessleri dominated by $\varepsilon$-proteobacteria (Alviniconcha (Epsilon)) and for Alviniconcha hessleri dominated by $\gamma$-proteobacteria (Alviniconcha (Gamma)). $\delta^{15} \mathrm{~N}$ of Alviniconcha hessleri is not documented, except for Alviniconcha sp. from Henry et al. (2008), which was used in this study

Table 1 Number of sequences representing each identified OTU in each sample investigated in this study. OTU names in bold correspond to full length sequences included in the phylogeny, the suffix '-p' indicates a partial sequence. Affiliation based on best BLAST hits: Epsilonproteobacteria (E), Deltaproteobacteria (D), Mollicutes (M) and Bacteroides (B). Names of samples are indicated by site (9 or 12), specimen ID (1 to 3 ) and tissue type (Gigill, VM-visceral mass, Sh-shell) as follows: site-specimen-tissue. Sum of sequences per OTU and percentage of total sequence counts are indicated. Finally, the two bottom rows indicate whether the OTU has no mismatch (+), a single mismatch (1mis) or more (-) to FISH probes Arc-94 and Epsy-549

Table 2: analysis of fragments of functional genes encoding APS reductase (aprA) and ATP citrate Lyase (ACL), their length, the identity of the represenative sequence, GENBANK accession number, percentage out of 70 (aprA) and 35 sequences (ACL), number of specimens in which the sequence occurred out of $3(\operatorname{aprA})$ and 2 (AclB), tissue occurrence (G: gill, R: visceral mass), and best hit according to BLASTX translated nucleotide sequence analysis

Supplementary material Fig S1: Phylogenetic reconstruction based on a 100 aa-long fragment of the $a c l B$ gene. A Maximum Likelihood approach using the JTT matrix-based model and a discrete Gamma distribution of evolutionary rates with a proportion of invariant sites was used. All bacteria from the ingroup are Epsilonproteobacteria, and the tree is rooted on two Aquificales. Boostrap percentage values based on 500 replicates are displayed. Scale bar corresponds to $10 \%$ estimated sequence divergence 

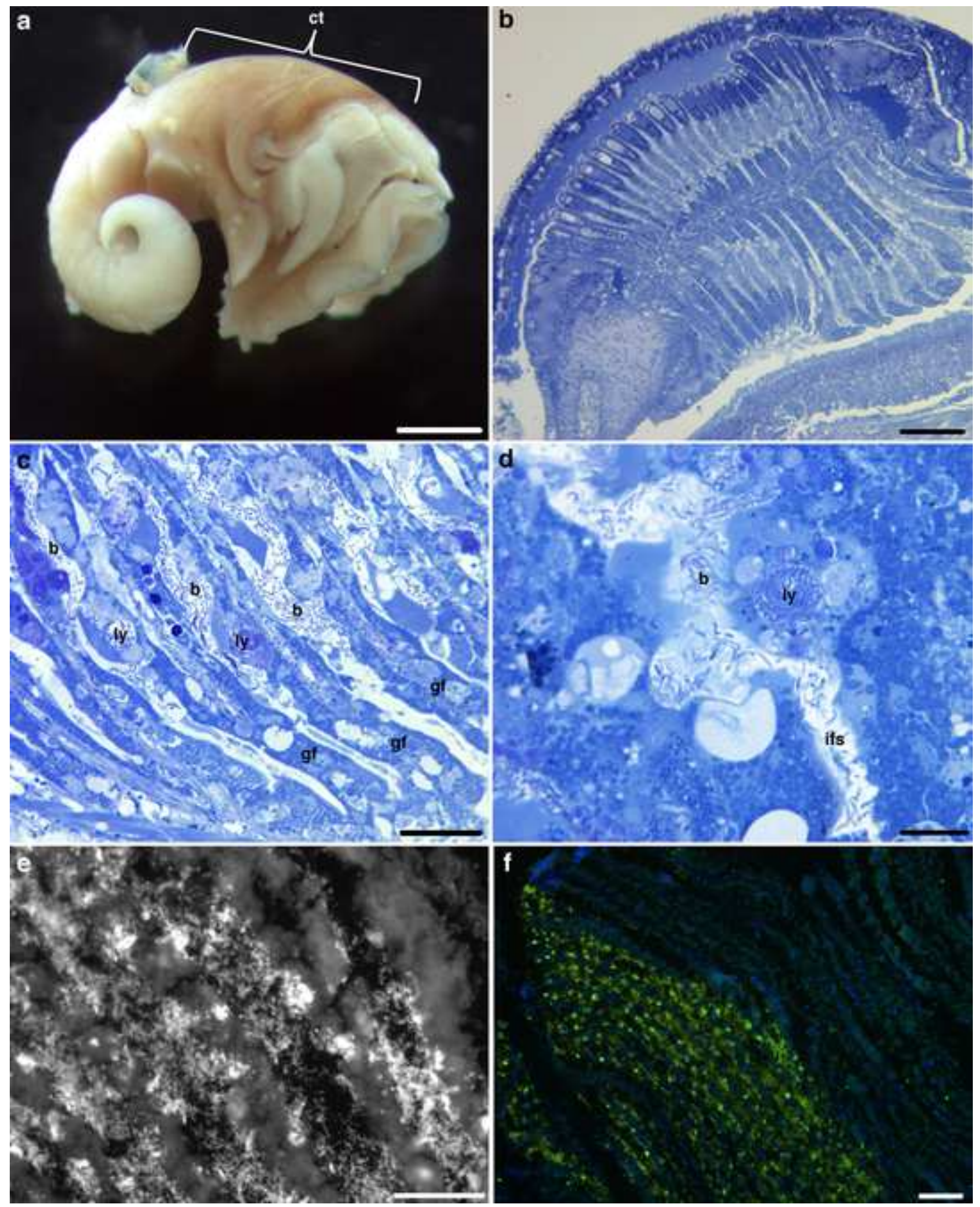
Click here to download high resolution image
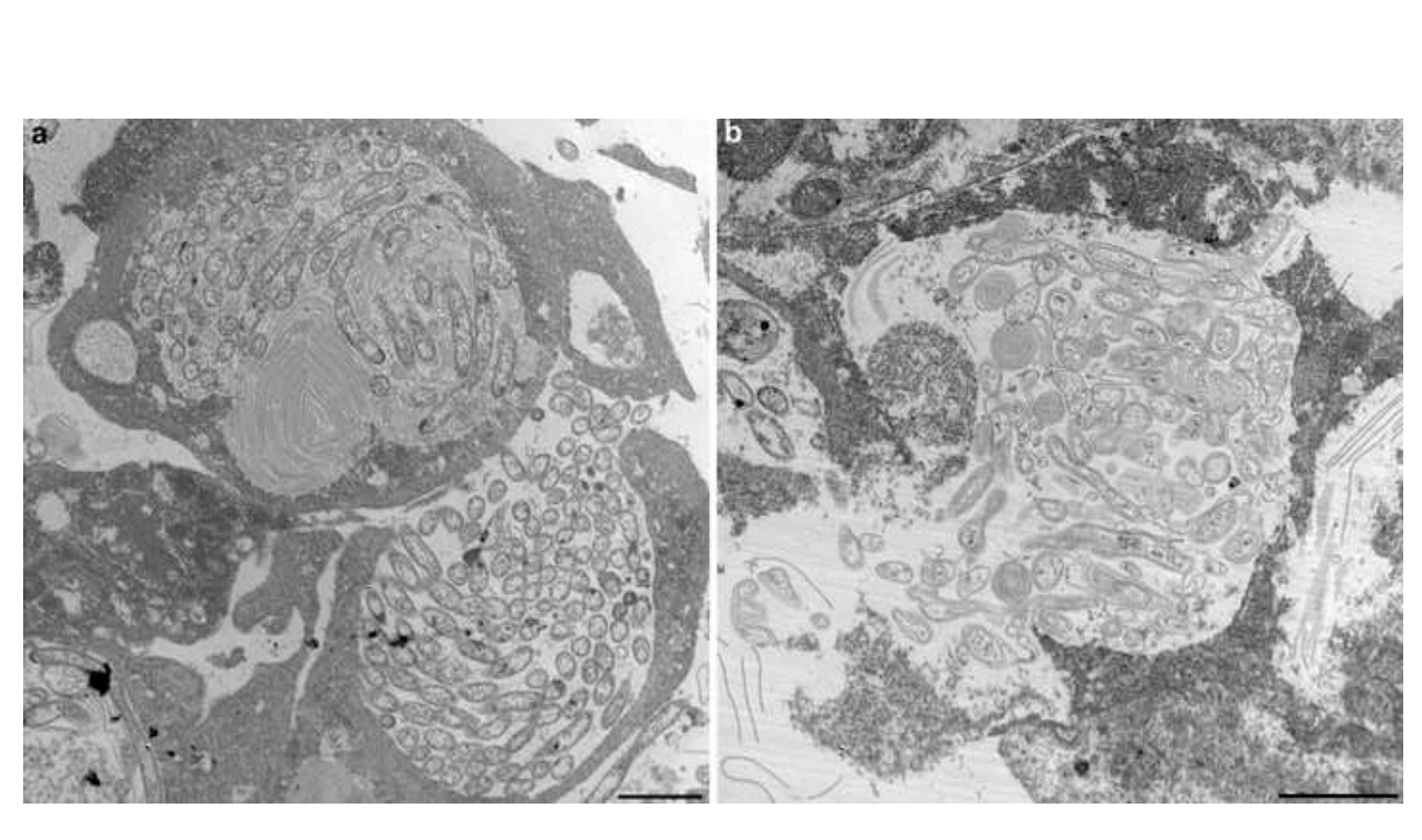

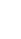
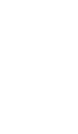

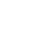

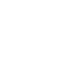

.




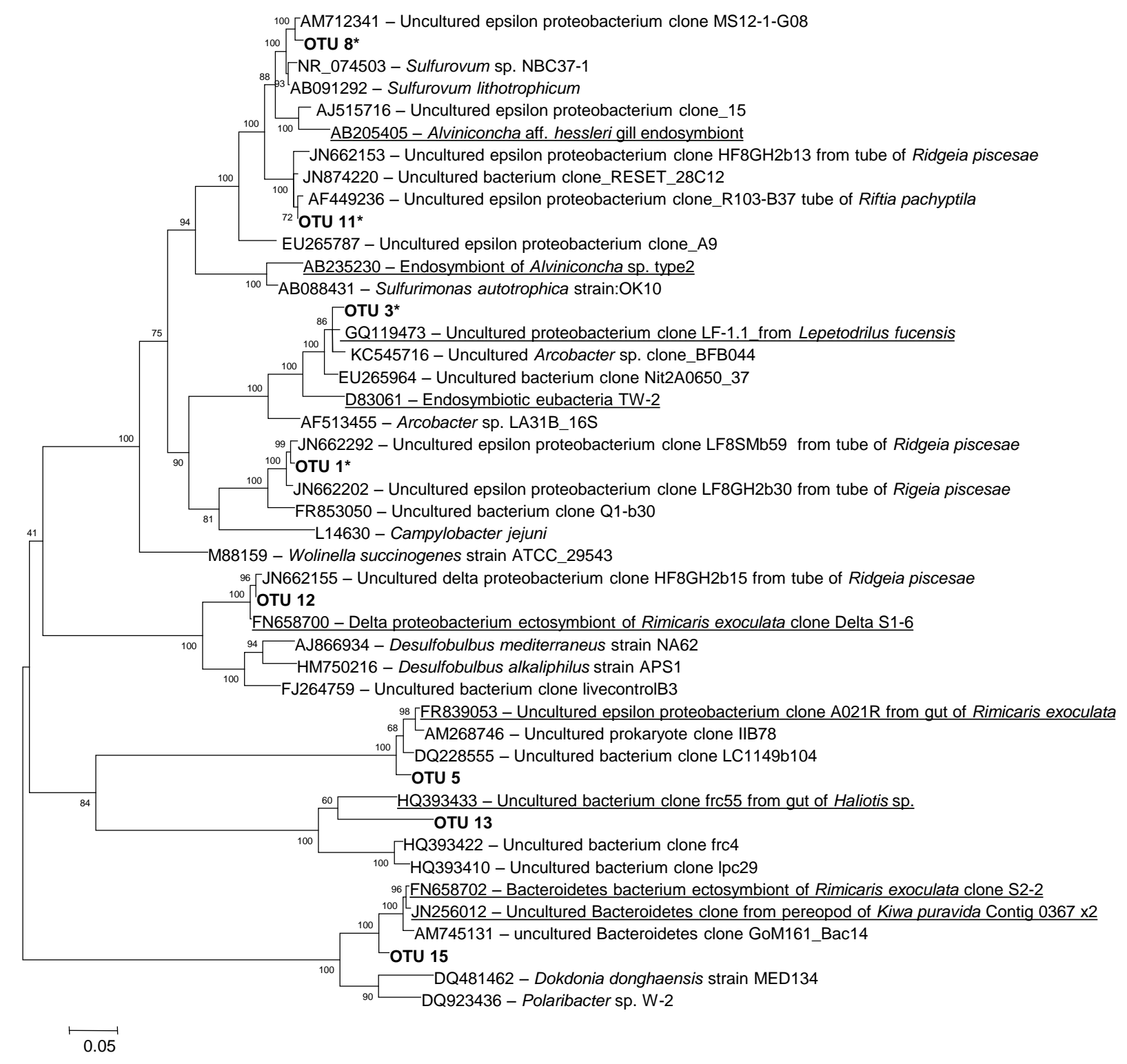




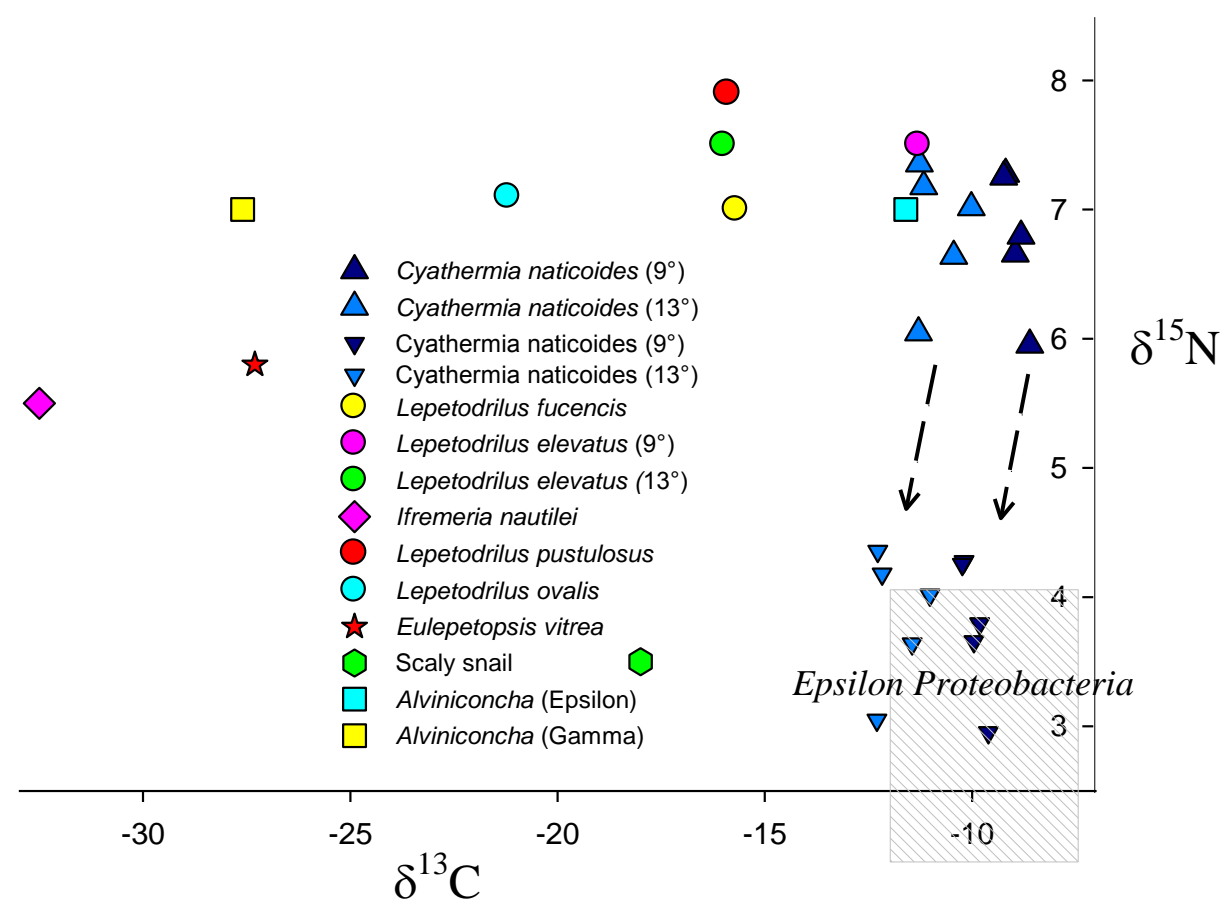




\begin{tabular}{|c|c|c|c|c|c|c|c|c|c|c|c|c|}
\hline OTU ID & $\mathbf{3}$ & 1 & 8 & 11 & 5 & 2-p & 16-p & 12 & 13 & 4-p & 15 & Sum \\
\hline Accession & KM213004 & KM213002 & KM213007 & KM213008 & KM213006 & KM213003 & KM213012 & KM213009 & KM213010 & KM213005 & KM213011 & \\
\hline Affiliation & $E$ & $E$ & $E$ & $E$ & $\mathrm{E}$ & $\mathrm{E}$ & $\mathrm{E}$ & $\mathrm{D}$ & $\mathrm{M}$ & $\mathrm{M}$ & $\mathrm{B}$ & \\
\hline 9-1-Gi & 7 & 7 & & & 1 & 4 & & & & 1 & & 30 \\
\hline 9-1-VM & 3 & 20 & 3 & & 1 & 3 & & & & 1 & & 32 \\
\hline 9-2-Gi & 14 & 7 & 3 & 1 & 5 & & & & & & & 32 \\
\hline 9-2-VM & 7 & 7 & 3 & & 5 & & & 4 & 1 & & 1 & 32 \\
\hline 9-2-Sh & & 9 & 14 & 2 & & & & 1 & & & 1 & 31 \\
\hline $9-3$ & 15 & 6 & 2 & & 1 & & 1 & 1 & 2 & 1 & & 32 \\
\hline 12-1-Gi & 11 & & & & & & & & & & & 11 \\
\hline 12-1-VM & & & 11 & 7 & & & & & & & & 19 \\
\hline 12-2-Gi & 5 & & 5 & 2 & & & & & & & & 17 \\
\hline 12-2-VM & & 2 & 3 & 3 & & & & & & & & 13 \\
\hline 12-3-Gi & 6 & & 2 & 1 & & & 3 & & & & & 17 \\
\hline 12-3-VM & & 1 & 11 & 5 & & & 1 & & & & & 29 \\
\hline \multicolumn{13}{|l|}{ Sum per } \\
\hline OTU & 68 & 59 & 57 & 21 & 13 & 7 & 5 & 6 & 3 & 3 & 2 & 244 \\
\hline Percentage & 23,05 & 20 & 19,32 & 7,12 & 4,41 & 2,37 & 1,69 & 2,03 & 1,02 & 1,02 & 0,68 & 82,71 \\
\hline Arc-94 & + & - & + & + & - & $1 \mathrm{mis}$ & + & - & - & - & - & \\
\hline Epsy-549 & + & $1 \mathrm{mis}$ & + & + & - & + & + & - & - & - & - & \\
\hline
\end{tabular}


Table 2

\begin{tabular}{|c|c|c|c|c|c|c|c|}
\hline Fragment & Approx length & Clone ID & $\begin{array}{c}\text { Accession } \\
\text { number }\end{array}$ & $\% /$ total & \begin{tabular}{|c|}
$\begin{array}{c}\text { Specimen } \\
\text { occurrence }\end{array}$ \\
\end{tabular} & $\begin{array}{c}\text { Tissue } \\
\text { occurrence }\end{array}$ & Best BLAST hit (BlastX) \\
\hline \multirow[t]{6}{*}{ aprA } & $365 \mathrm{nt}$ & 761 & KP115589 & 40.0 & 3 & $\mathrm{R}$ & 96\% EU265804 Epibiont of the vent crab Kiwa hirsuta (Gammaproteobacteria) \\
\hline & & 843 & KP115590 & 24.3 & 2 & $\mathrm{R}$ & 91\% GU197406 Bacterium associated with the Oligochete Tubificoides benedii (Gammaproteobacteria) \\
\hline & & 144 & KP115591 & 10.0 & 2 & $\mathrm{R}$ & $90 \%$ GU197406 Bacterium associated with the Oligochete Tubificoides benedii (Gammaproteobacteria) \\
\hline & & 820 & KP115592 & 18.6 & 2 & $\mathrm{R}$ & $100 \%$ FM165456 Bacterium associated with the tube of Lamellibrachia anaximandri (Gammaproteobacte \\
\hline & & 786 & KP115593 & 4.3 & 1 & $\mathrm{R}$ & 96\% EF633097 Bacterium associated with Echinocardium cordatum (Deltaproteobacteria) \\
\hline & & 827 & KP115594 & 1.4 & 1 & $\mathrm{R}$ & 97\% AM234053 Olavius algarvensis Delta-4 endosymbiont (Deltaproteobacteria) \\
\hline \multirow[t]{8}{*}{ AclB } & $305 \mathrm{nt}$ & 765 & KP115581 & 54.3 & 2 & G & 98\% FN659794 bacterium from branchial chamber of Rimicaris exoculata (Epsilonproteobacteria) \\
\hline & & 782 & KP115582 & 11.4 & & $G, R$ & 98\% FN908920 bacterium from hydrothermal fluid, Clueless (Epsilonproteobacteroa) \\
\hline & & 847 & KP115583 & 2.9 & 1 & $\mathrm{R}$ & 99\% FR670537 bacterium from Lucky Strike (Epsilonproteobacteria) \\
\hline & & 766 & KP115584 & 2.9 & 1 & $\mathrm{R}$ & 98\% FN659786 branchial chamber of Rimicaris exoculata (Epsilonproteobaceria) \\
\hline & & 805 & KP115585 & 2.9 & 1 & $\mathrm{R}$ & 98\% FN908920 bacterium from hydrothermal fluid, Clueless (Epsilonproteobacteria) \\
\hline & & 808 & KP115586 & 17.1 & & $R, G$ & $99 \%$ FN562694 bacterium from the Irina II vent, Logatchev (Epsilonproteobacteria) \\
\hline & & 840 & KP115587 & 2.9 & 1 & $\mathrm{R}$ & 99\% FN908925 Bacterium from the Logatchev vent field (Epsilonproteobacteria) \\
\hline & & 163 & KP115588 & 5.8 & 1 & $\mathrm{R}$ & 97\% FN562694 bacterium from the Irina II vent, Logatchev (Epsilonproteobacteria) \\
\hline
\end{tabular}

